\title{
The Impact of C \& D Waste on Indian Environment: A Critical Review
}

\author{
Sakshi Gupta* and Malik RK \\ Department of Civil Engineering, Amity University Haryana, India
}

Submission: April 12, 2018; Published: May 25, 2018

*Corresponding author: Sakshi Gupta, Department of Civil Engineering, Amity School of Engineering \& Technology, Amity University Haryana, India, Email: sakshigupta18489@gmail.com

\begin{abstract}
Construction industry is regarded as one of the foremost reasons of environment degradation worldwide. Waste is considered an apex issue in the construction sector because of its economic and ecological influences. From the past 25 years, the concentration on the Construction and Demolition (C \& D) waste has been developing from various academicians, investigators and experts worldwide. This study analyses the C \& D waste management and its effect on environment in India. The prime factors related to C \& D waste disposal that influence the environment adversely are dust and noise in India. The present study reviews the impacts of C \& D waste and their role in construction industry which is required for providing a hopeful and precautionary system for environmental management and protection. Suggestions have also been proposed to improve the condition of utilization of the $\mathrm{C} \& \mathrm{D}$ waste and making the environment sustainable. The issues discussed are suitable for construction managers and others related to the management of construction projects to have awareness of impacts of C \& D waste on the environment. It is suggested that the understanding and awareness of the project participants with respect to the impacts of construction processes on the environment needs to be strengthened.
\end{abstract}

Keywords: Construction activities; Waste; C \& D waste; Construction; Demolition; Environmental impacts; Sustainability

Abbreviations: C \& D: Construction and Demolition; MT: Million Tonnes; CPCB: Central Pollution Control Board; TPD: Tonnes Per Day; MSW: Municipal Solid Waste; ULBs: Urban Local Bodies; LCA: Life Cycle Assessment; DBOT: Design, Build, Operate \& Transfer

\section{Introduction}

After China, India is the second largest populated nation with over 1.29 billion population contributing $17.6 \%$ of the total population worldwide. In contrast, India is sharing $5 \%$ of the world's total area book-keeping for 3,185,263sq.km of which $68 \%$ lives in countryside and $32 \%$ lives in built-up zones i.e. cities, towns, etc. To provide housing facilities to the growing population, lots of construction activities are in progress. The construction primarily depends on the natural environment for the source of raw resources like wood, sand, timber and aggregates and in construction work large amount of debris is being produced. According to the Indian Government estimates, India produces at present about 165-170 million tonnes (MT) of debris annually and as per estimates of the Union Ministry of Urban Development, India produced 12-14.7 MT of C \& D waste per annum as reported by CPCB in March 2017.

According to Shen et al. [1], "C \& D waste is as a combination of surplus constituents generated from construction, renovation and destruction activities such as site clearance, land excavation and roadwork and demolition". The Solid Waste Management Rules [2] also defined C \& D waste as "Waste consisting of building materials, debris and rubble resulting from construction, remodeling, restoration and destruction of any civil construction". These wastes are bulky with high density and inhabit large storage area on the road and common waste bins or containers. It has been estimated that New Delhi itself generates at present about 4500 to 5000 tonnes per day (TPD) of C \& D Waste. The waste generation for new construction activities and re-construction activities has been estimated as 35 and $350 \mathrm{~kg} / \mathrm{sqm}$, respectively while about 2000 TPD C \& D waste is being received at the landfill sites in Delhi. Similar situations prevail in other metropolitan and large cities in India. As per the old report by the World Bank in 2012 , cities produced about 1.3 billion tonnes of solid waste per annum globally and this was predicted to rise to 2.2 billion tonnes by the year 2025. According to the studies, it has been revealed that building materials alone constitute about half of the solid waste produced throughout the world.

C \& D activities generate huge quantities of waste and more accumulation of waste is creating harmful effects on both environment and human life. Researchers around the world have reported that C \& D waste constitutes around 20 to $30 \%$ of total solid waste and about 70 to $80 \%$ of C \& D is concrete and masonry. 


\section{Civil Engineering Research Journal}

As C \& D waste forms a significant portion, the appropriate management of C \& D waste is vital for sustainable environment. Besides population increase, the boost in the fiscal growth after several advancements and re-development projects in India and subsequent rise in the urbanization and industrialization have made construction sector to boost remarkably, but the adverse environmental effects from the C \& D waste are progressively becoming challenging tasks in urban solid waste management [3]. This study assesses the impacts of construction and other civil engineering related activities on the environment and investigates the utmost serious challenges and hopeful measures for the management of C \& D waste particularly in India.

\section{Construction and Demolition Waste: Indian Scenerio}

The C \& D waste produced in the construction, preservation and discarding segments of a structure including waste from demolished structures, renovations and construction as well as repair of roads, flyovers, bridges, etc. is a composite waste stream and comprises of a varied range of constituents such as debris from the structures, bricks, concrete, soil, steel, timber (wood) and a mixture of site clearance materials that arises from several building activities. It also comprises occurrence of surplus consumptions in labour and energy used in various construction activities [4,5].

In India, it is a day-to-day practice for large C \& D projects to accumulate waste on the road sides leading to traffic congestion. C \& D waste from separate houses are dumped into neighboring municipal bins or containers and waste storing yards creating the bulky municipal waste and lowering its value for actions like energy recovery, composting, etc.

In January 2014, the then Minister of Urban Development informed the Parliament that no estimates exist for C \& D waste in India as it is very problematic to quantify the $\mathrm{C} \& \mathrm{D}$ waste. According to the Center for Science and Environment (CSE) located at New Delhi, the entire C \& D waste produced by buildings alone was estimated by 531 million tonnes in 2013 which was about 50 times higher than the existing official estimate. The Union Ministry of Forests and Environment (MoEF) has acknowledged that there is no organized evidences or database on the $\mathrm{C} \& \mathrm{D}$ waste. According to the estimations of CSE, India has recently built 5.75 billion sqm of extra floor space since 2010 with nearly 1 billion sqm in 2013. According to the Technology Information, Forecasting and Assessment Council (TIFAC), new construction produces 40$60 \mathrm{~kg} / \mathrm{sqm}$. of C \& D waste. Based on this, India produced almost 50 MT of C \& D wastes in 2013. From the past 8 years as per the estimates only for new construction, India produced about 287 MT of C \& D wastes. Demolition as well as renovation and repairrelated unused dump of the older stock create extra waste. The waste generated $300-500 \mathrm{~kg}$ per sqm of destruction is ten times of that produced during the construction phase as per TIFAC. It is assumed that annually $5 \%$ of the current building assets gets dismantled and reconstructed entirely and therefore, nearly 288 MT more of C \& D waste had been produced in the year 2013 itself due to demolition activities. TIFAC also reported that repair and maintenance of the buildings produces $40-50 \mathrm{~kg}$ per sqm of waste. If one-third of the current building assets gone through repair or renovation, India had produced typically 193 MT of C \& D wastes only from restoration and revamp in 2013. Thus, the entire C \& D waste produced only by buildings in 1 year i.e. 2013 amounts to 530 MT which is 44 times higher than the official estimates [5]. If the waste produced by other infrastructural developments such as roads and dams is also considered and then the C \& D waste is measured, it will be in excess of all the other kinds of solid waste placed all together. Where all this C \& D waste produced is going? The answer to this is that lot of waste is used to unlawfully stock up the water bodies and swamplands in the vicinity of the urban areas for industrial, commercial and housing development while the rest is dumped into the rivers, streams, etc. as well as open lands turning them into dump yards [6].

In India, some of the C \& D waste is re-utilized and recycled (near about 50\%) while the remaining is generally land-filled. Characterization findings on C \& D waste are negligible in India as it is typically aggregated and combined with municipal solid waste (MSW). The conventional constitution of C \& D waste in India according to three different surveys conducted by TIFAC [7], MCD and IL\&FS is presented in Table 1 as reported by Gayakwad \& Sasane in the year 2015.

Table 1: Conventional constitution of C \& D waste in India [3]

\begin{tabular}{|c|c|c|c|c|}
\hline \multirow{2}{*}{ S.No. } & \multirow{2}{*}{ Material } & TIFAC,2001 & $\begin{array}{c}\text { MCD Survey, } \\
\mathbf{2 0 0 4}\end{array}$ & $\begin{array}{c}\text { IL\&FS } \\
\text { Survey, 2005 }\end{array}$ \\
\cline { 2 - 5 } 1 & $\begin{array}{c}\text { Soil, sand and } \\
\text { gravel }\end{array}$ & 36 & 4 & 31.5 \\
\hline 2 & $\begin{array}{c}\text { Prick and } \\
\text { masonry }\end{array}$ & 31 & 15 & 59 \\
\hline 3 & concrete & 23 & 35 & - \\
\hline 4 & Metals & 5 & - & 0.4 \\
\hline 5 & Bitumen & 2 & - & - \\
\hline 6 & Wood & 2 & 2 & 7.6 \\
\hline 7 & Others & 1 & 7 & \\
\hline
\end{tabular}

Gayakwad \& Sasane [3] further reported that the waste generation during construction was estimated to be $40-60 \mathrm{~kg}$ per sqm. On similar basis, waste produced all through renovation and restoration work was projected to be $40-50 \mathrm{~kg}$ per sqm. The significant addition to C \& D waste production comes from the destruction of the buildings. Destruction of pucca and semi-pucca constructions typically produces 300 and $500 \mathrm{~kg}$ per sqm of waste, respectively.

Thus, it can be concluded from the various studies that there are various factors that affect the C \& D waste generation such as demographic factors like population, rate of urbanization, population density and socio-economic status of people; age of the city and construction and demolition patterns and practices [8]. 


\section{Civil Engineering Research Journal}

According to Dajadian \& Koch [9], the waste can be originated from the various operations and processes before, during and after construction. They found that there are several causes of construction waste according to the origin of the waste and they are classified accordingly as shown in Table 2.

Table 2: According to Dajadian \& Koch [9]; Origin and causes of construction waste.

\begin{tabular}{|c|c|}
\hline Origin of Waste & Causes of Waste \\
\hline Contractual & $\begin{array}{c}\bullet \text { Faulty contract papers } \bullet \text { Insufficient and } \\
\text { Incomplete contract documents }\end{array}$ \\
\hline Design & $\begin{array}{c}\bullet \text { Changes in design } \bullet \text { Design and construction } \\
\text { detail flaws } \bullet \text { Uncertain description } \bullet \text { Improper } \\
\text { management and communiqué }\end{array}$ \\
\hline Procurement & $\bullet \begin{array}{c}\bullet \text { Ordering mistakes } \bullet \text { Over-budgets } \bullet \text { Faults of } \\
\text { the suppliers }\end{array}$ \\
\hline Transportation & $\begin{array}{c}\bullet \text { Mutilation all through transportation } \bullet \\
\text { Inadequate method of unloading and protection } \\
\text { during unloading }\end{array}$ \\
\hline On-site & $\begin{array}{c}\bullet \text { Deficiency of on-site waste management } \\
\text { strategies and material control } \bullet \text { Insufficient } \\
\text { planning for required amounts } \bullet \text { Lack of } \\
\text { supervision }\end{array}$ \\
\hline $\begin{array}{c}\text { planning } \\
\text { Storage of Material }\end{array}$ & $\begin{array}{c}\bullet \text { Inadequate space for storage at site resulting } \\
\text { in damage or deterioration } \bullet \text { Inefficient } \\
\text { methods of storing the materials } \bullet \text { Materials } \\
\text { stored at farther distance from the point of use. }\end{array}$ \\
\hline Residual & $\begin{array}{c}\bullet \text { Loose supply of materials } \bullet \text { On-site } \\
\text { transportation methods from storage to the } \\
\text { point of use } \bullet \text { Inappropriate resource handling }\end{array}$ \\
\hline Handling of the \\
material
\end{tabular}

\section{Impact of C \& D Waste on Environment}

Buildings have long lifespan and their impacts affect the lives of many generations of our ancestors and stretch into the future of unknown resources, pollution and unstable climatic conditions [10]. Several investigations have shown that the consequences on the environment instigated by building activities are severe and require to be inhibited $[11,12]$. Building sector contributes majorly in the development of the society. While acknowledging this fact, it is also being professed as a key contributor to environment deterioration. Some of its negative effects on the society are land depletion, energy requirement and use, solid waste production, discharge of dust and gas, noise pollution, and utilization of natural resources including non-renewable resources [13]. In the past 100 years, the earth has heated by nearly $0.5{ }^{\circ} \mathrm{C}$ each year which is due to escalated concentrations of a few traces of greenhouse gases; most prominent among them being the carbon dioxide $\left(\mathrm{CO}_{2}\right)$ [14]. The energy use and associated $\mathrm{CO}_{2}$ emissions have been increasing at a faster rate globally over the past few decades. The impact of the continuous development of energy use are disastrous. The developed countries should enhance their energy efficiency to curb the problem of excessive energy use and thereby reducing the associated $\mathrm{CO}_{2}$ emissions. Construction industry related energy use is responsible for nearly half of India's energy use because of urbanization and industrialization. The use of non-renewable fuel source in the generation of resources, during the building practices, and by the dwellers or the end-users of the buildings/structures during their lifespan is a basis of large amount of $\mathrm{CO}_{2}$. The climatic changes due to the global warming are issuing a warning and treat to the environment and demands changes in the construction practices [15].

The most common effects on environment from various activities are dust, noise, smoke and odour (fugitive discharge). In circumstance of $C \& D$ waste management, the fundamental factors affecting the environment are dust and noise [9]. Earth movements, destruction and other building activities frequently includes the generation of spreading clouds of dirt with destructive impact on the growing figures of people suffering from respiratory diseases, and undesirable impact on the degradation surfaces. The dust generation activities also comprise of various restoration activities and dusting of façades. Also, setting up of dust-averting services must be imposed in such cases necessitating cautious assessment and assortment of appropriate precautionary measures [16]. Approximately 6 MT of waste from marble industries is being spread in India from various operations related to marbles such as cutting, processing, polishing, and grinding. Rajasthan having about 4000 marble mines alone has almost 95\% of the entire marble produced in India and can be thought-out as the major marble deposits in the world. Approximately $70 \%$ of the processing waste is being dumped in the neighborhood [1719]. The marble dust is mostly disposed on the riverbeds and possesses excessive environmental threat. The marble powder trails in the air, soars and deposits on flora and harvest during the dry season creating many hazards. All these incomparably impact the environment and local bionetworks. The marble dust dumped leads to the reduction in porosity and permeability of the top soil and causes the problem of water logging. Additionally, the minute constituent part of marble dust creates infertile soil because of the intensification in alkalinity.

According to a recent IIT Kanpur study in 2017, the main source of urban pollution was found to be road dust from C \& D Waste and making up $56 \%$ of course $\mathrm{PM}_{10}$ pollutants and $38 \%$ of the dangerous and respirable $\mathrm{PM}_{2.5}$ particles. Construction industry uses a set of pollutant fluids like paints, solvents, oils and washing water that may damage the land and nearby pavements. Such pollutant fluids should be cautiously used to reduce the pollution hazards on the ground. Workers should confine the use of unnecessary shuttering oil through proper usage of the products. Alternative oils derived from the vegetables and synthetic base are environmentally better but are expensive which can be recommended as they are less threatening for workers [20]. 
Noise produced by the construction activities at the site affect the peace, ease and healthiness of the residents and the visiting community and influences the general commotion of nearby schools, hospitals and other day-to-day services. The critical causes of noise are the demolition, operating various machinery at the site, pneumatic hammers, concrete mixers, re-processing of the C \& D waste, etc. There are various harmful impacts of the noise produced from C \& D waste disposal, re-processing and reuse to the environment urging the need to take initiatives and formulate the legislations in India.

\section{C \& D Waste Management}

\section{Common practices}

The management practices of waste from construction activities are endorsed with the goal of conserving the ecosystem recognizing the fact that wastes from C \& D works subsidize considerably to the polluted surroundings [21]. This booming consciousness of effects of C \& D wastes on environment has led to the growth of waste management as a valuable function of construction project management [1]. Currently, C \& D waste is regarded as a part of MSW. Except for a few isolated cases, C \& $\mathrm{D}$ waste is not managed properly in India by Urban Local Bodies (ULBs). The common practices of C \& D waste management include:

a. Reuse of valuable materials (by informal sector dealers)

b. Illegal open dumping: Debris consisting of concrete, brick and mortar. Excavated earth is dumped illegally on roadsides, low-lying areas and river beds. This causes the waste to pile up on roads causing inconvenience, choking surface drains, disrupting traffic and is an eyesore on the urban landscape.

c. Use as filler materials in low-lying areas especially before new construction.

d. Use in sub-base layer in roads.

e. Dumped in ULB designated dump yards (in a few cities only).

\section{Management strategies for C \& D wastes}

Various strategies have been taken up in different cities in India and are discussed as below:

a. C \& D waste management strategies exist in Delhi and Ahmedabad. Processing facilities have been set up in collaboration with private entities. Proper collection and transportation systems have been set up to aid processing. Illegal dumping practices are also discouraged due to penalties on open dumping.

b. Chennai and Kolkata are some exceptions to unaccounted C \& D waste production. Kolkata keeps records of the extent of C \& D waste getting dumped in landfills. Chennai is the only city which gives demolition permits to waste generators as compared to reconstruction permits given in other cities. This facilitates the estimation of C \& D waste generated based on area and type of the buildings demolished.

c. Many investigations have concluded a decline in environmental effects including $\mathrm{CO}_{2}$ emissions which can be ascribed to recycling of C \& D waste. Life cycle Assessment (LCA) studies can provide elementary guidance to design engineers and researchers working in this field [8].

Initiatives and Application of C \& D Waste Management

Good practices across the world offer lessons for developing, implementing and sustaining an efficient and adequate $C \&$ D waste management system. Several initiatives across the world show the approach to counterbalance the challenges faced by India in the management of C \& D waste. There have been various initiatives taken by state governments as well as central government in India which are summarized as:

a. $\quad$ PCB has come out with the detailed guidelines to act on dust mitigation measures for handling both on-site and offsite management of such waste in the cities and towns across India.

b. Timelines for the states have been planned to take into account key objective of the 'Swachh Bharat Mission' envisaging handing out of $100 \%$ solid waste produced in the cities or towns by October 2, 2019.

c. Dust control norms have been laid down in EPCA's Comprehensive Action Plan and the Graded Response Action Plan to minimize the pollution at construction sites.

d. The Solid Waste Management Cell of the Government of various states has given a noticeable position to $C \& D$ waste in their accomplishment plans.

e. Municipal Corporations in various parts of India have reported the "Construction and Demolition and De-silting Waste (Management and Handling) Rules, 2016."

f. The volume of C \& D waste produced in Delhi does not spread into the MSW stream as Municipal Corporation of Delhi (MCD) has definite transitional points for C \& D waste but appropriate discarding is problematic for the reason that the debris is disposed in the current landfills accumulating their space.

g. MCD has designated a Design, Build, Operate \& Transfer (DBOT) plan for adequate storage and assortment of 500 TPD C \& D waste from 3 MCD regions/zones, transportation to a recognized location and then processed and utilized. The rejected material would be land-filled at the same location. The DBOT partner; IL\&FS Waste Management and Urban Services Ltd. would also form a test road utilizing the processed C \& D waste with methodical support of Central Road Research Institute (CRRI), New Delhi which would be then supervised 
for more than a year. Hard work would be made for the growth of the market of processed C \& D waste.

h. Rules and regulations have been developed to reduce the construction waste thereby protecting the environment and improving sustainability of the construction sector.

i. Furnishing sufficient facts to the public at the time of applying for permission for the building/structure on the website and other modes including display at the zonal workplaces on the decorum and list of operators in the area $[22,23]$.

j. The C \& D Waste Management Rules, 2016 were announced by the Ministry of Environment, Forest and Climate Change (MoEF \& CC) on 29 $9^{\text {th }}$ March 2016 and came into effect since then.

k. Pilot initiatives in Delhi, Ahmedabad and Bengaluru have shown that C \& D waste can be recycled and reused in construction and such efforts have produced commendable results.

Some of the applications of the C \& D waste management concepts are mentioned below:

a. A school building in Rajkot, Gujarat has been built utilizing the rubble of Bhuj earthquake which was designed by Ahmedabad based architect Surya Kakani.

b. The Institute of Rural Research and Development (IRRAD) building in Gurugram, Haryana has creatively recycled and re-utilized its own construction waste during the construction of the same building itself.

c. Initiatives are being taken by building administrators or Resident Welfare Associations (RWAs) in townships in India to collect and dispose C \& D waste. RWAs in condominiums in Gurugram, Haryana have issued notices to home owners not to mix C \& D waste with MSW. The waste is collected in separate bins and transported to designated dumpsites by contractors. Such initiatives have shown the increasing levels of awareness on C \& D waste in India.

d. Low cost housing and Integrated Low-Cost Sanitation (ILCS) program government buildings and civil structures have also been proposed.

e. Contractors at some site in India have taken the initiative to reuse some of the materials. Reuse of bricks, stone slabs, timber (wood), channels, etc. at site to the likely amount and confined to their condition.

f. Selling or auctioning the resources which cannot be used or are in the unused condition at the site due to design constraints or changes in the design or over-ordering.

g. Plastics, broken glass, scrap metals, etc. are being used by recycling manufacturing units. h. Debris, brick bats, fragmented plaster, concrete fragments, etc. have been utilized for building purposes, such as under coat of lanes where there are not much heavy traffic loads, leveling, etc.

In India, creative steps are being taken even though legal transformation is consuming a lot of time. It has been seen from various studies that in prevailing policy environment, the economic benefits of C \& D waste recycling facility are not very attractive. However, if environmental and social benefits could be monetized, C \& D waste recycling facility becomes very viable option for waste management [24-26].

\section{Suggestions/Recommendations}

Based on the various surveys conducted related with the $\mathrm{C}$ \& D waste management, the following recommendations and suggestions are proposed:

a. Detailed waste management strategy should imitate the magnitude and complications involved with the project's waste issues.

b. Constantly amending the waste management strategy to report how waste is handled and review where waste is captured.

c. Environment-friendly technologies should be utilized for C \& D waste management.

d. Offer training about the waste management strategy to the people concerned.

e. Building activities may deteriorate flora on site and in its surroundings. As trees are important natural elements of urban landscape, utmost care must be taken to guarantee their protection.

f. Assessment of the level of noisegenerated by construction locations will absolutely be established in the future owing to the requirement to follow the rules and regulations and to evade any undue claims from the neighborhood. Distinctive site organizational measures must be adopted.

g. Lean construction techniques must be adopted outlining the procedures relate to the elimination of waste.

h. Sustainable or green building practice must be adopted to reduce, re-use, and recycle the C \& D waste. Advocating 'deconstruction' in place of 'demolition' and developing designs which aid 'deconstruction'.

i. Waste recycling strategies should be promoted for C \& D projects prior to the commencement of the construction activity.

j. Statutory orders, action plans and voluntary agreements must be carried out.

k. Banning of landfills with C \& D waste must be done to reduce air/land pollution and hence help the environment 


\section{Civil Engineering Research Journal}

from toxic waste and gases.

l. Promoting recycling and developing market for recycled products

m. Awareness circulars or notices can be issued to communicate the citizens about the new C \& D waste assortment and dumping system and the locations of the bins and direct the citizens to discard the $C \& D$ waste in the designated bins only or directly to the $C$ \& D facility site. The civic authority must alert that no person should discard C \& D waste on the pavements, streets, open land, drainage (storm) or areas associated with the municipality or the government. If such waste is disposed on a private property, the owner of that property would be obligated for the disposed waste and would be held accountable for any kind of deterioration of the surrounding area or causing pollution.

n. Mandating compliance of a C \& D Waste management plan by massive generators of C \& D waste (>400sqm of construction)

o. Enforce a construction waste charge on developers and the revenue generated can be utilized to support and subsidize C \& D waste recycling centers.

p. Consistently dismantle the structure or the building instead of destroying them.

q. It can also be suggested that the Government can offer tax concessions to $\mathrm{C} \& \mathrm{D}$ recycling centers and bring out various tax policies to minimize waste production and avoid hazardous disposal.

r. Barricading the area, cleaning the vehicles before leaving the construction site, covering vehicles carrying construction material, using of wet jet for grinding and stone cutting and sprinkling recycled water at the site can be some of the measures to minimize the pollution at construction sites.

Thus, there must be an appropriate institutional system to take utmost care of the assortment, transportation, transitional storage (if necessary), utilization and discarding of C \& D wastes. Rightful rules and regulations should be formulated and instigated at each level. Segregation of C \& D waste must be encouraged at source of waste and private enterprise can be advantageously engaged for the assortment and transportation of that waste. In India, PublicPrivate-Partnership (PPP) schemes can be a potential system of utilizing of C \& D waste management [15].

\section{Conclusion}

To economize the resources from the earth such as river sand, stone, soil, etc. and energy to protect the environment from various pollutants, C \& D waste management requires to be focused upon. C \& D waste has potential use after processing and the application such waste is typical in industrialized countries but in India so far, no systematized effort has been made but some NGOs and Private companies have taken the initiative to reduce, reuse and recycle the $C \& D$ waste. There is an enormous challenge to manage C \& D waste in the future. Data should be created on C \& D waste production and its characteristics to assess the waste and its potential re-use, reduction or recycling. There should be easy admittance to the data pertaining to C \& D production, governmental and regulatory framework and measures to all stakeholders and public. There is a need for countries like India to take up inter-disciplinary research in all areas related C \& D waste management. With the growth of the economy leading to increased construction activity, it is important that this area is addressed in a mission mode to ensure sustainable growth.

Thus, in India, the level of knowledge and awareness and the obtainability of technology for C \& D waste re-utilization and recycling require to be enhanced to make a sustainable transformation. Quality standards for the recycled or re-used products are required to be formulated and carefully supervised by Bureau of Indian Standards.

\section{References}

1. Shen LY, Tam VW, Tam CM, Drew D (2004) Mapping Approach for Examining Waste Management on Construction Sites. Journal of Construction Engineering and Management 130(4): 472-481.

2. MoEF \& CC (2015) Draft Solid Waste Management Rules, 2015. New Delhi: Ministry of Environment, Forest and Climate Change, Government of India.

3. Gayakwad HP, Sasane NB (2015) Construction and Demolition Waste Management in India. International Research Journal of Engineering and Technology (IRJET) 2(3): 712-715.

4. Kofoworola OF, Gheewala SH (2009) Estimation of construction waste generation and management in Thailand. Waste Management 29(2): 731-738.

5. Thomas J, Wilson PM (2013) Construction waste management in India. American Journal of Engineering Research (AJER) 2: 06-09.

6. Shrivastava S, Chini A (2009) Construction Materials and C \& D waste in India. Conference on Life Cycle Design of Buildings Systems and Materials: Book of Abstracts, Florida, pp. 20.

7. TIFAC (2001) Utilization of Waste from Construction Industry. Technology Information, Forecasting and Assessment Council, New Delhi.

8. Satyanarayana KN, Ram VG (2015) Recycling of C \& D Waste -Sustainability and Research Issues. Department of Civil Engineering Indian Institute of Technology Madras, Workshop on Construction \& Demolition Waste Recycling (CDWR) 28th February 2015 JNTUH, Kukatpally, Hyderabad.

9. Dajadian SA, Koch DC (2014) Waste Management Models and Their Applications on Construction Sites. International Journal of Construction Engineering and Management 3(3): 91-98.

10. Crawley D, Aho I (1999) Building environmental assessment methods: applications and development trends. Building Research and Information 27(4-5): 300-308.

11. Bossink BAG, Brouwers HJH (1996) Construction Waste: Quantification and Source Evaluation. Journal of Construction Engineering and Management 122(1): 55-60.

12. Ling YY, Lim MCH (2002) Implementation of a waste management plan for construction projects in Singapore. Architectural Science Review 45(2): 73-81. 


\section{Civil Engineering Research Journal}

13. Lu W, Yuan H (2010) A framework for understanding the waste management studies in construction. Waste management 31(6): 1252 1260 .

14. Lenzen M, Treloar GJ (2002) Embodied energy in buildings: wood versus concrete-reply to Börjesson and Gustavsson. Energy Policy 30(3): 249-255.

15. Mandlik PP, Mohammad G, Morey S, Malik S, Khan S (2017) C \& D Waste Material Management in Construction Industry of Nagpur Region. International Research Journal of Engineering and Technology 4(3): 417-420.

16. Teixeira JMC (2005) Construction site environmental impact in civil engineering education. European Journal of Engineering Education 30(1): 51-58.

17. Gupta TN (1998) Building materials in India: 50 years, a commemorative volume. Building Materials Technology Promotion Council, New Delhi, India: Government of India

18. Saxena M, Asokan P (2002) Timber substitute products from industrial solid wastes. In: Rajisnish Srivastava (Eds.), Proceedings of the $18^{\text {th }}$ national convention of environmental engineers and national seminar on solid waste management, Bhopal, India, pp. 192-200.

19. Dak H (2000) Conservation of water and disposal of marble waste by using filter press. In: Department of Mining Engineering, Udaipur Proceedings of the National workshop on Safety \& Technology in Marble Mining and Processing in new Millennium, Department of Mining Engineering, CTAE, Udaipur, India.

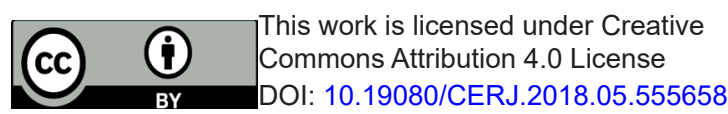

20. Teixeira J, Couto A (2000) Construction sites and environment in historic Portuguese cities. CIB Symposium on Construction and Environment, São Paulo, Brazil.

21. Shen LY, Tam VWY, Tam CM (2002) Material Wastage in Construction Activities-A Hong Kong Survey. Proceedings of the CIB W107 1st International Conference: Creating a Sustainable Construction Industry in Developing Countries, South Africa p. 11- 13.

22. Behera M, Bhattacharyya SK, Minocha AK, Deoliya R, Maiti S (2014) Recycled aggregate from C \& D waste \& its use in concrete-A breakthrough towards sustainability in construction sector: A review. Construction and Building Materials 68: 501-516.

23. Bansal S, Singh SK (2014) A Sustainable Approach towards the Construction and Demolition Waste. International Journal of Innovative Research in Science, Engineering and Technology 3(2): 9226-9235.

24. Khandelwal P (2015) Construction and Demolition Waste Processing a Pioneering Initiative by Delhi. Workshop on Construction \& Demolition Waste Recycling (CDWR) 28 $8^{\text {th }}$ February 2015 JNTUH, Kukatpally, Hyderabad

25. (2017) CPCB Guidelines on Environmental Management of C \& D Wastes (Prepared in compliance of Rule 10 sub-rule 1(a) of C \& D Waste Management Rules, 2016).

26. Gulghane AA, Khandve PV (2015) Management for Construction Materials and Control of Construction Waste in Construction Industry: A Review. Int Journal of Engineering Research and Applications 5(4): $59-64$

\section{Your next submission with Juniper Publishers will reach you the below assets}

- Quality Editorial service

- Swift Peer Review

- Reprints availability

- E-prints Service

- Manuscript Podcast for convenient understanding

- Global attainment for your research

- Manuscript accessibility in different formats

(Pdf, E-pub, Full Text, Audio)

- Unceasing customer service

Track the below URL for one-step submission https://juniperpublishers.com/online-submission.php 